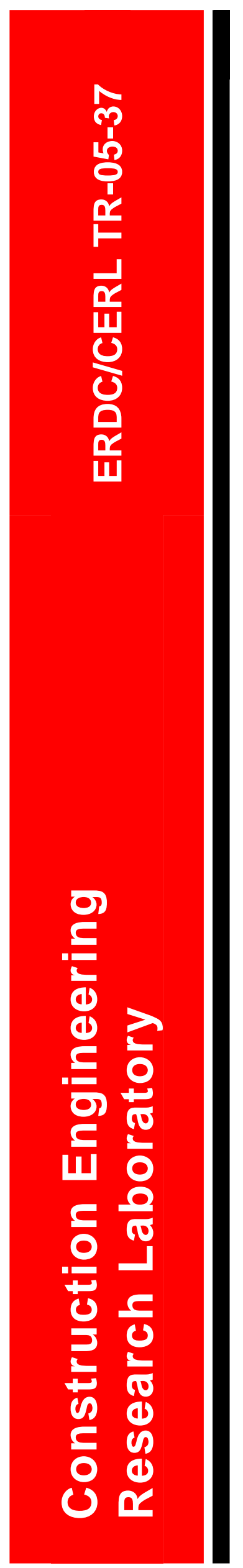

\title{
Available Conservation Research for Fort Bliss
}

Jeffrey S. Fehmi and Bruce A. MacAllister

November 2005 


\section{Available Conservation Research for Fort Bliss}

Jeffrey S. Fehmi and Bruce MacAllister

Construction Engineering Research Laboratory

PO Box 9005

Champaign, IL 61826-9005

Approved for public release; distribution is unlimited.

Prepared for Office of the Directorate of Environmental Programs (DAIM) Assistant Chief of Staff (Installation Management) (ACS[IM]) Fort Bliss 


\section{ABSTRACT}

In the last 10 years there have been numerous conservation-related research projects conducted on and related to Fort Bliss, Texas. These projects, while supporting Fort Bliss's conservation goals, have been done by numerous federal agencies and other non-governmental organizations, universities, and consultants. The resulting combination of technical reports, masters theses, doctoral dissertations, research articles, and proceedings papers make it difficult for managers to distill the appropriate pieces of the research into answers to their land management questions. This project was initiated to summarize and consolidate the available research on conservation, natural resources, and land management at Fort Bliss into a more cohesive and usable form. A secondary objective was to provide a number of the reports in electronic form for easier access and to help ensure that the reports remain available beyond the one copy or the few printed copies now in existence.

DISCLAIMER: The contents of this report are not to be used for advertising, publication, or promotional purposes. Citation of trade names does not constitute an official endorsement or approval of the use of such commercial products. All product names and trademarks cited are the property of their respective owners. The findings of this report are not to be construed as an official Department of the Army position unless so designated by other authorized documents. 


\section{CONTENTS}

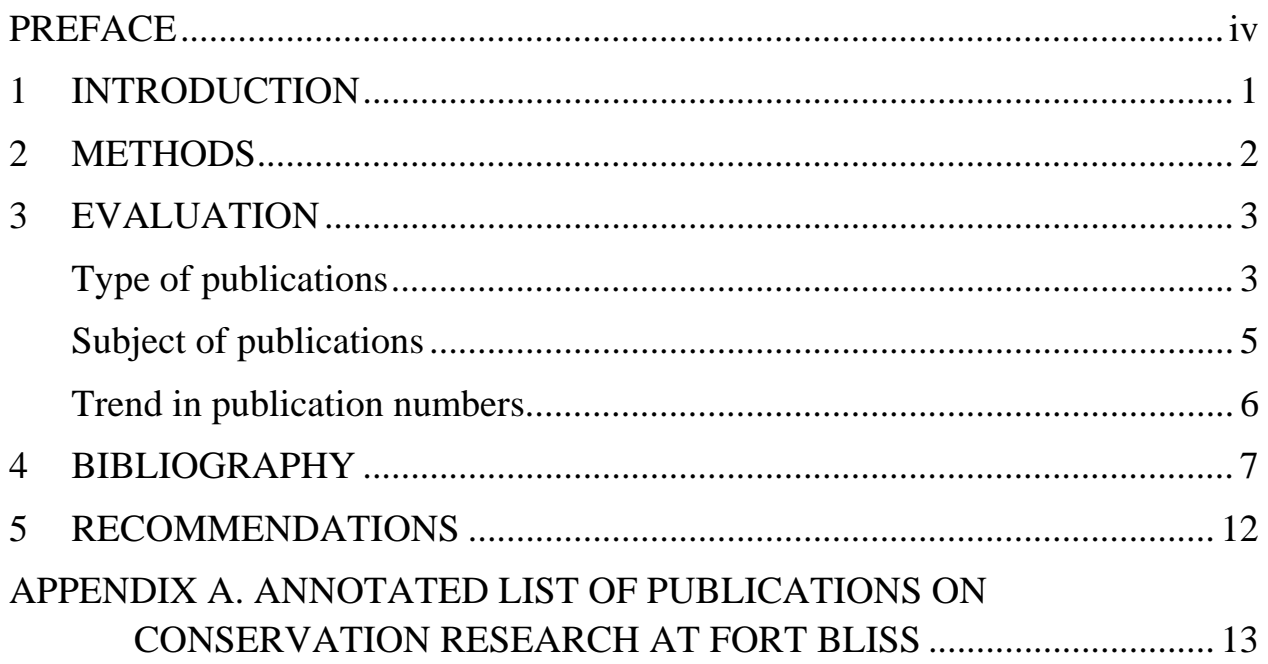

\section{ILLUSTRATIONS}

Figure 1. Numbers of publications by decade. ............................................... 6

\section{TABLES}

Table 1. Types and numbers of publications describing research at Fort Bliss..... 3 Table 2. Subjects and numbers of publications describing research at Fort Bliss. 5 


\section{PREFACE}

This report was prepared by Dr. Jeffrey S. Fehmi, Ecologist, Ecological Processes Branch; and Dr. Bruce A. MacAllister, Natural Resource Specialist, Ecological Processes Branch, both of the Construction Engineering Research Laboratory (CERL), Engineer Research and Development Center (ERDC), Champaign, Illinois. The managers at Fort Bliss were Kevin vonFinger and Brett Russell. The technical editor was David Cate, Information Technology Laboratory. Mr. Stephen Hodapp is Chief, CEERD-CN-N, and Dr. John T. Bandy is Chief, CEERD-CN. The associated Technical Director was Dr. William D. Severinghaus, CEERD-CV-T. The Director of CERL is Dr. Alan W. Moore.

This study was conducted for the Office of the Directorate of Environmental Programs (DAIM), Assistant Chief of Staff (Installation Management) (ACS[IM]) under project 622720896, "Environmental Quality Technology;” Work Unit CNN-T081. The technical monitor was Dr. Vic Diersing, DAIM-EDN.

The Commander and Executive Director of the Engineering Research and Development Center is COL James R. Rowan. The Director is Dr. James R. Houston. 


\title{
Available Conservation Research for Fort Bliss
}

\author{
JEFFREY S. FEHMI AND BRUCE A. MACALLISTER
}

\section{INTRODUCTION}

In the last 10 years there have been numerous conservation-related research projects conducted on and related to Fort Bliss, Texas. These projects, while supporting Fort Bliss's conservation goals, have been done by numerous federal agencies and other non-governmental organizations, universities, and consultants. The resulting combination of technical reports, masters theses, doctoral dissertations, research articles, and proceedings papers make it difficult for managers to distill the appropriate pieces of the research into answers to their land management questions.

This project was initiated to summarize and consolidate the available research on conservation, natural resources, and land management at Fort Bliss into a more cohesive and usable form. A secondary objective was to provide a number of the reports in electronic form for easier access and to help ensure that the reports remain available beyond the one copy or the few printed copies now in existence. These products of this Conservation Assistance Program project will greatly improve the future allocation of research at Fort Bliss as well as improve the breadth and depth of the use of previously completed research. 


\section{METHODS}

A search for the available research was undertaken in three ways. First, the peer-reviewed literature was searched through commercially available databases such as Current Contents, Web of Science, Biological Abstracts (BIOSIS), and JSTOR. Second, the National Technical Information Service (http://www.ntis.gov/index.asp) and other military-specific databases were searched (e.g., the ERDC virtual library at http://libweb.wes.army.mil). Finally, the available records through ERDC-CERL were searched for research that was completed or contracted though our organization.

The research was compiled into a bibliography, and the available abstracts were input into a reference database (Endnote 6.0). These data were sorted into summary tables. Available publications were scanned and saved as Portable Document Format (PDF) files on electronic media for transfer to the installation. 


\section{EVALUATION}

\section{Type of publications}

The database of research at Fort Bliss was separated in a variety of ways. First, the documents were broken out according to the type of publication (Table 1). The majority of the publications in the database were journal articles. This is largely because journal articles are indexed, and citations are readily available through a variety of databases and search engines. In addition, journals typically have a wide distribution and are thus available from a variety of sources accessible to the public. Because of these attributes, it is likely that many of the sources from journal articles were located. Articles of this type that were not located are likely to be in obscure journals. Another reason for missing articles pertaining to work done at Fort Bliss could be that there was no mention of the installation in the title, subject, or abstract fields that are searchable in most journal article databases.

\begin{tabular}{|lc|}
\hline $\begin{array}{l}\text { Table 1. Types and numbers of } \\
\text { publications describing research } \\
\text { at Fort Bliss. }\end{array}$ \\
\hline \multicolumn{1}{|c|}{ Type of publication } & Number \\
\hline Journal articles & 29 \\
Book sections & 2 \\
Theses/dissertations & 16 \\
Conferences & 2 \\
NEPA & 16 \\
Published reports & 17 \\
Unpublished reports & 25 \\
\hline Total & 107 \\
\hline
\end{tabular}

The second most common publication type was unpublished reports. Of the 25 unpublished reports, 11 were range or resource reports that either directly or indirectly supported land management decisions related to NEPA (National Environmental Policy Act). The remaining 14 were research-related reports. This kind of report is often difficult to chance upon. Even when one knows of such a report's existence, it is often impossible to locate. Unpublished or draft reports 
are not indexed or archived in an accessible manner. Generally, if several years have passed, even the author(s) will be unable to locate copies of the reports. This is the least desirable category of documentation because once the copies transmitted to the installation disappear, the report and any associated research findings or data have been lost. While some of the information in the unpublished reports may be included in journal articles or theses/dissertations, relatively few of the existing unpublished documents have likely been located. This type of document would benefit most from publication.

The sixteen NEPA documentation reports could also be included in the unpublished report category. However, the public review aspect of this kind of documentation often means that there is a searchable index of the available documents, and there is at least one archive (at Northwestern University) from which these documents may be requested. These documents are currently handled appropriately, and no additional public indexing or archiving seems needed.

The seventeen published reports represent a good type of research documentation. Published reports are typically indexed in a variety of places and are available from the organization that published them. Often the content of these reports does not fit into the length, type, or subject matter of typical peerreviewed journals, and a published report seems a good alternative. However, if the material in the report could instead be published in a journal, that is a much more broadly disseminated venue and should be preferred over a report. It seems likely that many of the conservation-related published reports were located.

There were 13 Masters theses and $3 \mathrm{PhD}$ dissertations located that had been completed from work related to or on Fort Bliss. This kind of document is indexed and available typically from the institution from which the student graduated. Many theses and dissertations are also archived nationally. The only researchers for whom this type of publication is an option are students. This kind of publication is often difficult to read and may take a fair amount of effort to extract useful and important information. Many of the existing publications of this type were likely located.

There were two book sections located. This type of publication can be difficult to identify, but once identified, they are easy to locate because of the broad distribution of most books. This kind of publication is not an option for most research. It is difficult to assess if there are more book chapters that were not identified.

There were two conference presentations identified. Conference abstracts are not often indexed or archived. Tracking conference presentations is recommended because the abstracts of these presentations or posters can serve as 
a way to find people and associated bodies of research pertaining to specific conservation subjects. There are likely many conference abstracts that were not identified in this search.

\section{Subject of publications}

It was difficult to categorize the publications by subject. Most publications touch on more than one area because the natural systems are interrelated. For instance, the management papers typically included some information about the vegetation and soil, since these are important in any evaluation of an activity's impact. Nonetheless, it seemed useful to look at the broad categories of studies that have been published from work at Fort Bliss (Table 2).

\begin{tabular}{|c|c|}
\hline Publication subject & Number \\
\hline Wildlife & 36 \\
\hline Water/erosion/soils/hydrology & 19 \\
\hline Managment & 20 \\
\hline McGregor & 13 \\
\hline Vegetation & 10 \\
\hline Roving sands/related & 9 \\
\hline Total & 107 \\
\hline
\end{tabular}

The single most published subject was wildlife, with roughly a third of the total publications. Perhaps this could be attributed to the fact that of all the organisms listed by the U.S. Fish and Wildlife Service, wildlife is the most common as a group. Another reason for the high representation of wildlife publications is that notes about species occurrences or behaviors represent about half the total of these types of publications. Species occurrences merely document a species inhabiting an area in which they were previously unrecorded. Wildlife and vegetation both typically represent basic research, and the numbers of these publications show the importance of basic research to the overall research program.

The categories that were expected to be the most prevalent (and taken collectively are common) were the NEPA-related McGregor, Roving Sands, and 
Management plan reviews. Roving Sands is the world's largest air and missile defense exercise held annually at Fort Bliss on the McGregor Range in NM. As these documents are mandated, this is the appropriate level of publication. The other publications in management and water/erosion/soils/hydrology could potentially benefit from further publication in venues with wider public readership.

\section{Trend in publication numbers}

The first natural-resources-related publications for Fort Bliss (of the ones that could be located in this search) appeared in 1976. Since then there has been a steady increase in the number of publications coming out each year (Fig. 1). While this search only extended through mid-2003, there were already 33 publications for this decade. Based on a linear increase, there will be at least 75 total publications for this decade. This trend shows the strong progress in supporting natural-resources-related research that has taken place since the 1970s.

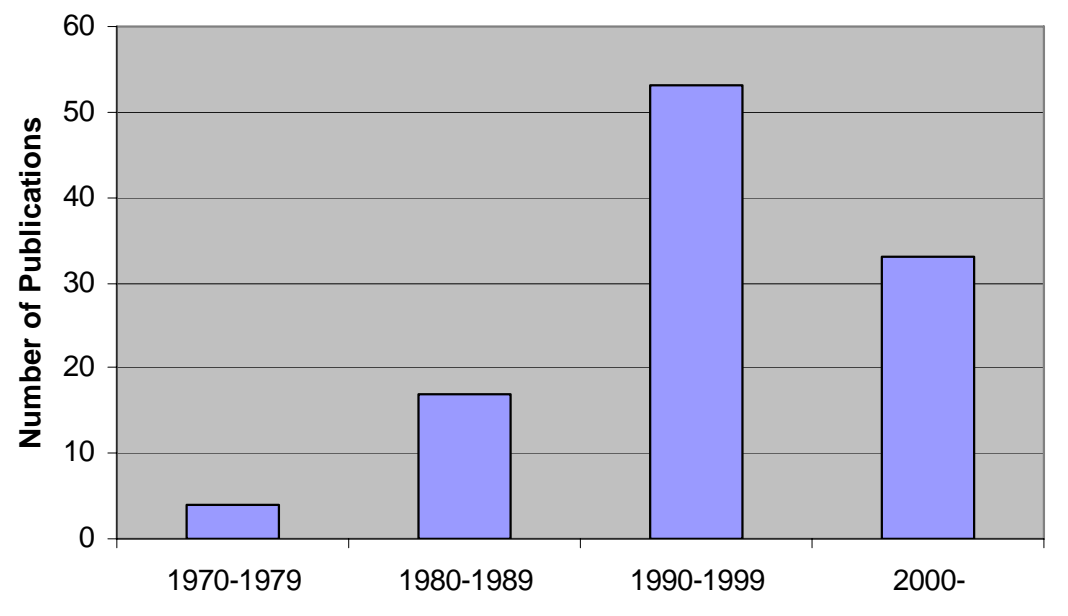

Figure 1. Numbers of publications by decade. 


\section{BIBLIOGRAPHY}

A complete bibliography of the following references is attached as Appendix A. A CD with the electronic files of the reports marked with an ' $x$ ' is also attached. These files are in .pdf format and require Adobe Acrobat Reader@ to read them. Document inclusion depended on availability at the time this report was completed. Copyright considerations may limit further the distribution of the book and journal publications.

For a copy of the CD contact Dr. Bruce MacAllister (217) 373-4439.

Abeyta (1996) Ground-water quality, water year 1995, and statistical analysis of ground-water...

Abeyta (1996) Hydrogeology and ground-water quality of the chromic acid pit site, U.S. Army...

囚 Anderson (1996) Land condition trend analysis data: Power analysis

$\square$ Anonymous (1976) Land use withdrawal, McGregor Range, Fort Bliss, Texas: draft...

Anonymous (1980) A cockroach (Blatta lateralis) - Texas - new state record. Cooperative-Plant...

Anonymous (1980) Draft environmental impact statement on grazing management in the...

Anonymous (1980) Grazing management: McGregor EIS Area, New Mexico.

Anonymous (1981) McGregor Range rangeland management program document.

Anonymous (1982) McGregor range, rangeland management program document: update report.

Anonymous (1985) White Sands Resource Area rangeland program summary: annual update.

Anonymous (1986) White Sands Resource Area rangeland program summary: annual update.

Anonymous (1987) McGregor range rangeland management program document: update report.

- Anonymous (1988) White Sands resource management plan amendment/ environmental impact...

Anonymous (1989) Proposed White Sands resource management plan amendment/ final...

Anonymous (1990) Resource management plan amendment: McGregor Range

Anonymous (1993) Draft programmatic environmental impact statement for the Joint Training...

Anonymous (1993) Final environmental assessment for the Roving Sands 93 Joint Training...

Anonymous (1994) Final programmatic environmental impact statement for the Joint Training...

- Anonymous (1997) Supplemental environmental assessment for Joint Training Exercise Roving...

$\square$ Anonymous (1998) McGregor range land withdrawal, Fort Bliss, Otera County, New Mexico.

Anonymous (1999) Programmatic environmental assessment for Joint Exercise Roving Sands 
Anonymous (2001) McGregor Range resource management plan amendment and environmental...

Bak (2001) Distribution of wintering ferruginous hawks (Buteo regalis) in relation to black...

$\square$ Bandy (1983) Distribution of water use at representative fixed Army installations

囚 Boykin (2001) Application and assessment of species at risk: Conservation approaches at...

$\square \quad$ Boykin (1997) Biotic and physical attributes of surface and near-surface water sites on Fort...

凶 Breland (2001) Automatic classification of vegetation and land degradation with large-scale...

囚 Bright (2002) Remote sensing users' guide: Version 2.5

$\square \quad$ Burkett (1992) Evaluation of relative wildlife use associated with water units on White Sands...

$\square \quad$ Burkett (2000) Cnemidophorus tigris (western whiptail).

$\square \quad$ Burkett (2000) Cnemidophorus uniparens (desert grassland whiptail).

$\square$ Burkett (2000) Leptotyphlops humilis (western blind snake).

$\square \quad$ Burkett (2000) Rhinocheilus lecontei (longnose snake).

․ Burkett (2000) Sceloporus magister (desert spiny lizard).

$\square \quad$ Burkett (2000) Uta stansburiana (side-blotched lizard).

$₫ \quad$ Childress (2002) Applying a complex, general ecosystem model (EDYS) in largescale land...

凶 Childress (1999) A functional description of the Ecological Dynamics Simulation (EDYS)...

$\square \quad$ Cionco (1978) Analysis of canopy index values for various canopy densities.

\Clary (1999) Checklist of mammals from twelve habitat types at Fort Bliss Military Base...

凶 Clary (2002) Small mammal communities and habitat associations in the Chihuahuan Desert...

$\square$ Cockman (1996) Identification of classification parameters for ephemeral drainages in the ...

凶 Coldren (2001) Application of the EDYS model to a training area landscape at Fort Bliss...

$\square$ Couvillion (1980) Survey for antibodies to viruses of bovine virus diarrhea, bluetongue and...

$\square$ Del Divine (1992) Vegetational and ungulate utilization analysis of artificial wildlife $\ldots$

$\square \quad$ Demarais (1999) Ecosystems of disturbed ground.

\ Fowler (1994) Competitive pricing for the McGregor range; Implications for federal grazing fees.

$\square \quad$ Frenzel (1999) Geohydrology of the unsaturated zone and simulated time of arrival of landfill...

\ Fuchs (1997) Sediment removal by water following mechanical surface disturbance on...

$\square \quad$ Gallacher (1991) Grazing fee evaluation on McGregor Range: A competitive market situation.

$\square \quad$ Geo Marine Inc. (1994) Ft. Bliss integrated natural resources management plan: Scoping report.

$\square$ Gibbs (1997) A cultural and natural resources survey of approximately 7.3 miles of pipeline... 
囚 Gillespie (1987) The impact of military maneuvers on eolian transport and soil compressive...

Gilliland (1977) The use of systems diagrams for environmental impact assessment...

\ Goran (1983) An overview of the ecological effects of tracked vehicles on major US Army...

凶 Hamazaki (2001) Incorporating landscape context in conservation planning models for Fort...

Hamazaki (2003) Analysis of ecological context for identifying vegetation and animal...

Hansen (1976) Foods of free-roaming horses in southern New Mexico

\ Hernando (1999) Effects of military wheeled vehicles on soil compaction in the Chihuahuan...

$\square \quad$ Heywood (2003) Simulated ground-water flow in the Hueco Bolson, an alluvialbasin aquifer...

Hinojos (1988) Metazoan parasites of Himantopus mexicanus muller (Aves) from southwestern...

凶 Hochstrasser (2002) A bibliography of important plant species in the Chihuahuan Desert of...

Johnson (1997) Geomorphological, geoecological, geoarcheological, and surficial mapping...

囚 Jones (1996) Ecological studies on McGregor Range hydrologic studies task: Final report

Jorgensen (1998) Herpetofauna associated with arroyos and uplands in foothills of the...

凶 Jorgensen (1995) Rodent use of microhabitat patches in desert arroyos

Jorgensen (1998) Modeling habitat suitability for small mammals in Chihuahuan Desert...

Jorgensen (1994) The effect of box-trap design on rodent captures.

$\square \quad$ Kozma (1995) Cooperative nesting between barn swallows and Say's phoebes in South...

Kroll (2000) Comparative ecology and conservation of the genus Ashmunella (Gastropoda...

Kroll (2001) Habitat characteristics and conservation of the genus Ashmunella (Gastropoda...

Kroll (2003) Comments on the natural history of the Ashmunella (Gastropoda : Pulmonata...

Kroll (2003) Habitat characteristics and conservation of the genus Ashmunella (gastropoda...

MacKay (1996) The impact of wheeled vehicle maneuvering on the flora and fauna of the...

MacKay (1996) The impact of wheeled vehicle maneuvering on the flora and fauna of the...

凶 MacKay (1997) The impact of wheeled vehicle maneuvering on the flora and fauna of the...

Martin-Bashore (1996) An annotated bibliography and natural history database of the...

\ McLendon (1999) EDYS 2: First year validation results for a black grama desert grassland... 
囚 McLendon (2000) EDYS Applications: Two-year validation results for grassland communities...

\ McLendon (2001) EDYS experimental and validation results for grassland communities...

\ McLendon (1998) A successional dynamics simulation model as a factor for determining...

凶 Mendoza (1997) The impact of wheeled vehicle maneuvering on the flora and fauna of the...

$\square \quad$ Minor (1999) Evaluating change in rangeland condition using multitemporal AVHRR data and...

囚 Montes-Helu (1997) Track-vehicle disturbance on rangeland and design of SAP flow gauge for...

凶 Perez (1999) Impact of military wheeled vehicles on water infiltration rates of Chihuahuan...

\ Perez (1999) Impact of wheeled vehicle maneuvering on soils of the Chihuahuan Desert...

凶 Pidgeon (2000) Avian abundance and productivity at the landscape scale in the northern...

$\square \quad$ Pidgeon (2003) Landscape-scale patterns of black-throated sparrow (Amphispiza Bilineata)...

$\square \quad$ Rivieccio (2000) Validation of predictive habitat modeling for the Colorado chipmunk (Tamias...

$\square \quad$ Rivieccio (2004) Habitat features and predictive habitat modeling for the Colorado chipmunk in...

\ Rodrick (1999) Morphological, genetic and den site characteristics of the kit fox ("Vulpes...

$\square$ Rodrick (1999) Characteristics of natal and non-natal kit fox dens in the northern Chihuahuan...

$\square \quad$ Science Applications International Corporation (1998) Fort Bliss mission and master plan...

$\square \quad$ Science Applications International Corporation (1998) McGregor Range land withdrawal draft...

$\square \quad$ Science Applications International Corporation (1998) McGregor Range, New Mexico land...

$\square \quad$ Science Applications International Corporation (1998) McGregor Range, New Mexico land...

凶 Science Applications International Corporation (1999) McGregor Range land withdrawal...

$\square \quad$ Science Applications International Corporation (2000) Fort Bliss mission and master plan final...

$\square \quad$ Silcox (1995) Impacts of wheeled vehicles on surface water, infiltration, and erosion: Fort Bliss

$\square \quad$ Smith (1998) Diets of native and non-native ungulates in southcentral New Mexico

$\bowtie \quad$ Stafford (1986) Fort Bliss soil degradation study

凶 Tweddale (2001) Historical analysis of land cover/condition trends at Fort Bliss, Texas, using...

\ Tweddale (2002) Estimating vegetation cover case study spectral demixing and spectral...

$\square \quad$ United States Army Air Defense Artillery Center (1998) Integrated natural resources... 
URS Corporation (2001) McGregor Range resource management plan amendment and...

$\square \quad$ Vogel (1996) Effects of fire on herpetofauna of the northern Chihuahuan Desert, Fort Bliss...

Wilson (1981) Ground-water resources of the Soledad Canyon re-entrant and adjacent areas...

凶 Wood (1996) Final report: Surface water and erosion component tank maneuver studies 


\section{RECOMMENDATIONS}

Fort Bliss should continue its electronic repository of research data and add the new reports as the research is completed. Approximately every three years, the new reports should be reviewed in the context of the existing body of work, and a summary report should be produced in which the main findings are disseminated along with a summary of the current research report holdings. This will facilitate new and existing employees' understanding of the scope of work performed at Fort Bliss while encouraging the use of currently available research about the installation.

It is recommended that Fort Bliss begin tracking conference presentations of work done on the installation because the abstracts of these presentations or posters can serve as a way to find people and associated bodies of research about specific conservation subjects.

Fort Bliss should encourage publication of reports from research conducted at the installation. This has three purposes. It gets the message out to the community that the installation supports scientific research. This in turn shows that the installation's active conservation program is interested in the state of the art and will allow outsiders to view the lands and the program. Finally, publication of the research formally documents it for future use, because as time passes and those employees directly involved with the work move on, the information gets lost. With publication, the core findings are maintained and the authors can still be contacted for further information or clarification. 


\section{APPENDIX A. ANNOTATED LIST OF PUBLICATIONS ON CONSERVATION RESEARCH AT FORT BLISS}

Abeyta, C.-G., and R.-G. Roybal (1996) Ground-water quality, water year 1995, and statistical analysis of ground-water-quality data, water years 1994-95, at the chromic acid pit site, U.S. Army Air Defense Artillery Center and Fort Bliss, El Paso, Texas. Water Resources Investigations Report 96-4211, U.S. Geological Survey. 45 p.

Abeyta, C.-G., and C.-L. Thomas (1996) Hydrogeology and ground-water quality of the chromic acid pit site, U.S. Army Air Defense Artillery Center and Fort Bliss, El Paso, Texas. Water Resources Investigations Report 96-4035, U.S. Geological Survey. 67 p.

Anderson, A.B., P.J. Guertin, and D.L. Price (1996) Land condition trend analysis data: Power analysis. CERL TR-97/05, U.S. Army Construction Engineering Research Laboratory, Champaign, IL.

The Land Condition Trend Analysis (LCTA) program is the Army's standard for land inventory and monitoring, employing standardized methods of natural resources data collection, analyses, and reporting designed to meet multiple goals and objectives. LCTA data has been used to characterize installation natural resources, evaluate the effects of Army multiple use demands on training lands, groundtruth remote sensed imagery, and as a source of data for land based carrying capacity modeling efforts. A critical element of many of these applications is the ability of LCTA data protocols to detect changes in installation natural resources. This report presents results of a study that used power analysis techniques to evaluate the ability of LCTA data collection protocols to detect changes in installation resources. The use of information and techniques presented in this report should increase land managers' confidence in conclusions drawn from studies using LCTA data by providing the information necessary to adequately judge the strength of evidence from those studies.

Anonymous (1976) Land use withdrawal, McGregor Range, Fort Bliss, Texas: Draft environmental impact statement. U.S. Army Air Defense Center, Fort Bliss, TX, U.S. Army Training and Doctrine Command.

Anonymous (1980) A cockroach (Blatta lateralis) - Texas - new state record. Cooperative Plant Pest Report, U.S. Department of Agriculture. 
Blatta lateralis (Wlk.) is recorded for the first time in Texas. In June 1979, infestations so heavy that eradication was impracticable were found in two buildings at Fort Bliss and in a vacant residential building at Biggs Field, all in El Paso County.

Anonymous (1980) Draft environmental impact statement on grazing management in the McGregor EIS area. Las Cruces District Office, U.S. Bureau of Land Management.

Anonymous (1980) Grazing management: McGregor EIS Area, New Mexico. Las Cruces District Office, U.S. Bureau of Land Management. 98 p.

Anonymous (1981) McGregor Range rangeland management program document. Las Cruces District Office, U.S. Bureau of Land Management. 14 p.

Anonymous (1982) McGregor range, rangeland management program document: Update report. Las Cruces District Office, U.S. Bureau of Land Management.

Anonymous (1985) White Sands Resource Area rangeland program summary: Annual update. Las Cruces District Office, U.S. Bureau of Land Management.

Anonymous (1986) White Sands Resource Area rangeland program summary: Annual update. Las Cruces District Office, U.S. Bureau of Land Management.

Anonymous (1987) McGregor range rangeland management program document: Update report. Las Cruces District Office, U.S. Bureau of Land Management.

Anonymous (1988) White Sands resource management plan amendment/ environmental impact statement for McGregor Range: Draft. White Sands Resource Area, U.S. Bureau of Land Management.

Anonymous (1989) Proposed White Sands resource management plan amendment/final environmental impact statement for McGregor Range. Las Cruces District Office, U.S. Bureau of Land Management. 131 p.

Anonymous (1990) Resource management plan amendment: Mcgregor Range. Las Cruces District Office, U.S. Bureau of Land Management. 51 p.

Anonymous (1993) Draft programmatic environmental impact statement for the Joint Training Exercise Roving Sands at Fort Bliss, Texas and New Mexico and White Sands Missle Range, New Mexico. U.S. Army Corps of Engineers, Fort Worth District; U.S. Forces Command.

Anonymous (1993) Final environmental assessment for the Roving Sands 93 Joint Training Exercise at Fort Bliss, Texas and New Mexico and White Sands Missile Range, New Mexico. U.S. Army Corps of Engineers, Fort Worth District; Geo-Marine, Inc. 
Anonymous (1994) Final programmatic environmental impact statement for the Joint Training Exercise Roving Sands at Fort Bliss, Texas and New Mexico and White Sands Missle Range, New Mexico. U.S. Army Corps of Engineers, Fort Worth District.

Anonymous (1997) Supplemental environmental assessment for Joint Training Exercise Roving Sands 97, Texas and New Mexico. U.S. Army Forces

Command; Army Corps of Engineers, Fort Worth District.

Supplement to the Programmatic environmental impact statement (PEIS) for the Joint Training Exercise Roving Sands at Fort Bliss, Texas and New Mexico, and White Sands Missile Range, New Mexico, prepared in 1994.

Anonymous (1998) McGregor range land withdrawal, Fort Bliss, Otera County, New Mexico. U.S. Army Corps of Engineers, Fort Worth, Texas; Army EPA number: 980439D. 586 pages and maps.

The renewal of the withdrawal of land supporting the military mission of the U.S. Army with respect to the McGregor Range at Fort Bliss, located in southern New Mexico, is proposed. 609,935-acre McGregor Range has supported the mission of Fort Bliss since the 1940s. The range encompasses 609,385 acres of public domain lands, 71,083 acres held in fee ownership by the Army, and 1,010 acres of previously state-owned lands transferred to the Bureau of Land Management after 1986. The range also includes 18,004 acres of U.S. Forest Service lands used by the Army in accordance with a memorandum of understanding between the Forest Service and the Army. In 1986, public lands, comprising McGregor Range were withdrawn from the public domain for a period of 15 years. This withdrawal expires November 6, 2001. The range is used primarily for training in intercepting and destroying missiles and aircraft in flight. Systems used at the range include the Patriot missile system, Avenger, Stinger, Bradley, Linebacker, and other advanced weapons systems. The Army's application for renewal of the McGregor Range withdrawal for military use would extend the withdrawal through the year 2051. Six alternatives, including a No Action Alternative (Alternative 5), are considered in this draft EIS.

Under the Army's proposed action (Alternative 1), the boundaries of the range would be coterminous with those of the 1986 withdrawal. Under Alternative 2, only the Tularosa Basin and Otero Mesa portions of the range, encompassing 569,395 acres, would be withdrawn for continued military use, while the Sacramento Mountains foothills portion of the range, including the Culp Canyon Wilderness Study Area, would return to the public domain. Under Alternative 3, only the 429,395-acre Tularosa Basin portion of the range would be withdrawn, while the Otero Mesa and Sacramento Mountains 
foothills would be returned to the public domain. Under Alternative 4, only the 365,395-acre portion of the Tularosa Basin south of New Mexico Highway 506 would be withdrawn. Under Alternative 6, the Congress would establish a national conservation area on Otero Mesa and designate Culp Canyon as a wilderness area; Otero Mesa and the Sacramento Mountains foothills portion of the range would be returned to the public domain. POSITIVE IMPACTS: The renewal of the land withdrawal would provide sufficient space to conduct real-world military training, maintaining quality military and operational readiness standards, supporting military education and training programs, and allowing joint Army, Navy, Air Force, and Marine training exercises. The procurement activities at the fort would continue to support the local economy. NEGATIVE IMPACTS: Civil aircraft would continue to be prohibited from traversing portions of the range with the restricted area was activated. Missile firings and use of off-road vehicles during training operations would disturb soils and vegetation and the associated wildlife habitat as well as cultural resource sites. Noise and visual intrusions associated with military operations would continue. Increases in the use of hazardous materials and items of special concern could result from ongoing and future military uses as well as nonmilitary activities that occur on the withdrawn lands. LEGAL MANDATES: Engle Act of 1958 (43 U.S.C. 155 et seq.), Federal Land Policy and Management Act of 1976 (43 U.S.C. 1701 et seq.), and Military Lands Withdrawal Act of 1986 (P.L. 99606).

Anonymous (1999) Programmatic environmental assessment for Joint Exercise Roving Sands. U.S. Army Corps of Engineers, Fort Worth District; U.S. Army Forces Command.

Anonymous (2001) McGregor Range resource management plan amendment and environmental impact statement. Scoping notice. Las Cruces District Office, Bureau of Land Management.

The Bureau of Land Management (BLM), Las Cruces Field Office, is preparing a resource management plan amendment (RMPA) and environmental impact statement (EIS) to address BLM's management of the public land withdrawn for military use within McGregor Range in southern Otero County, New Mexico.

Bak, J. M., K.G. Boykin, B.C. Thompson, and D. Daniel (2001) Distribution of wintering ferruginous hawks (Buteo regalis) in relation to black-tailed prairie dog (Cynomys ludovicianus) colonies in southern New Mexico and northern Chihuahua. Journal of Raptor Research, 35(2): 124-129. 
Bandy, J.T., and R.J. Scholze (1983) Distribution of water use at representative fixed Army installations. Technical report N-157, U.S. Army Construction Engineering Research Laboratory, Champaign, IL. 107 p.

Boykin, K.G., J. Bak, A.J. Kroll, M. Rivieccio, R.A. Deitner, B.C. Thompson, and M.C. Andersen (2001) Application and assessment of species at risk conservation approaches at Fort Bliss and White Sands Missile Range, New Mexico and Texas. New Mexico Cooperative Fish and Wildlife Research Unit. 176 p.

Boykin, K.G., P.L. Matusik, D. Houde-Nethers, and B.C. Thompson (1997) Biotic and physical attributes of surface and near-surface water sites on Fort Bliss Military Reservation: Inventory and comparative assessment. New Mexico Cooperative Fish and Wildlife Research Unit. 88 p.

Breland, A. E. (2001) Automatic classification of vegetation and land degradation with large-scale, color infrared, aerial imagery. Masters Thesis, University of Nevada.

The use of aerial, color infrared, digital imagery was examined as a tool for monitoring land degradation from training on the Fort Bliss military reservation in New Mexico. Principal components analysis and raster correlation matrices were utilized to interpret image variance. High color band correlation and a predominance of the spatial aspect of imagery was determined. A color space conversion and low pass filtering in frequency space were employed as pre-classification image processing techniques to enable vegetation patch delineation. Ecologically significant classes relating to vegetative disturbance and recovery stages were automatically extracted with an unsupervised classification algorithm. Range ecology models of Seral Stages and Increaser/Decreaser/Invaders were used to label classification results.

Bright, T.A., and S. Getlein (2002) Remote Sensing Users' Guide. Version 2.5. SFIM-AEC-EQ-TR-200053, U.S. Army Environmental Center (USAEC), U.S. Army Corps of Engineers Engineer Research and Development Center Topographic Engineering Center (TEC) and Construction Engineering Research Laboratory (CERL).

Burkett, D.W. (1992) Evaluation of relative wildlife use associated with water units on White Sands Missile Range. M.S. Thesis, New Mexico State University.

Data gathered in this study suggest that overall species richness is not enhanced by the addition of water. No differences in ungulates (mule deer, oryx, pronghorn, horses, cows) at water sources versus comparison sites were found. 
Burkett, D.W., and D. Black (2000) Cnemidophorus tigris (western whiptail). Herpetological-Review, 31(2): 112.

Burkett, D.W., and D. Black (2000) Cnemidophorus uniparens (desert grassland whiptail). Herpetological-Review, 31(2): 112.

Burkett, D.W., and D. Black (2000) Leptotyphlops humilis (western blind snake). Herpetological-Review, 31(2): 114.

Burkett, D.W., and D. Black (2000) Rhinocheilus lecontei (longnose snake). Herpetological-Review, 31(2): 114.

Burkett, D.W., and D. Black (2000) Sceloporus magister (desert spiny lizard). Herpetological-Review, 31(2): 113.

Burkett, D.W., and D. Black (2000) Uta stansburiana (side-blotched lizard). Herpetological-Review, 31(2): 113.

Childress, M.W., D.L. Price, C. Coldren, and T. Mclendon (1999) A functional description of the Ecological Dynamics Simulation (EDYS) model, with applications for Army and other federal land managers. CERL TR-99/55, U.S. Army Construction Engineering Research Laboratory, Champaign, IL.

In FY95, USACERL initiated the "Land Based Carrying Capacity" capability package. The impetus behind this research and development package was the coincidence of needs from the Office of the Deputy Chief of Staff for Operations (ODCSOPS), the Office of the Directorate of Environmental Programs (ODEP) and several installations, to address the requirement of sustainable training and testing land carrying capacity. A key component of this capability package is the Ecological Dynamics Simulation (EDYS) model. The model provides the capability to predict responses of training lands to both military and non-military stressors and facilitates linking the cost of training and testing land maintenance to the actual level of training. We provide here a functional description of the EDYS model with applications for several Army installations, the U.S. Air Force Academy, and the National Water Management Center of the USDA Natural Resources Conservation Service. We also have included appendices that describe system implementation, and data requirements and structure. The EDYS model will be incorporated into the Land Management System (LMS) and will be available to users via the Corps' Engineer Research and Development Center web site.

Childress, W.M., C.L. Coldren, and T. Mclendon (2002) Applying a complex, general ecosystem model (EDYS) in large-scale land management. Ecological Modelling, 153(1-2): 97-108. 
A critical need in the management of public and non-urban private lands in the United States and elsewhere is assessing the efficacy of different management alternatives under different environmental and land use scenarios. One type of tool that would be extremely valuable is large-scale ecological simulation models designed to project effects of alternative climatic, usage, and management scenarios on ecological resources. A modeling challenge in this type of application is to link mechanistic simulations of small-scale 'ecosystem' processes to large-scale 'landscape' processes to provide more realistic and exhaustive projections of effects and ramifications of management alternatives. The Ecological DYnamics Simulation model (EDYS) is a general ecosystem simulation model that mechanistically implements relevant processes in ecosystem dynamics, including: climatic inputs, soil water and nutrient dynamics, plant uptake and growth by species, herbivory, fire, contaminants, physical disturbance, and management activities. In the EDYS model, ecological processes simulated in plot-level ecosystem cells are scaled up to the landscape level using a gridbased representation of the spatial extent of that ecosystem across the landscape. A significant practical challenge in applying complex ecological models is compilation of appropriate input data from a wide-variety of print and on-line media. A semi-automated database is currently under development, which will compile, organize, and format data sets to facilitate future EDYS applications. Another challenge is linking different types of models, each of which is specialized to simulate particular aspects of ecosystem and landscape dynamics. As so many different types of organizations are presently involved in model development and resource management, ownership of models and datasets will increasingly become an issue in their distribution and use among different types of land managers.

Cionco, R.M. (1978) Analysis of canopy index values for various canopy densities. Boundary Layer Meteorology, 15(1): 81-94.

Canopy wind profiles can often be represented by an exponential function such that windspeeds in these vegetative canopies are a function of height and the attenuation coefficient of this wind profile relationship. Canopy flow is a function of canopy density, element flexibility and height. An index of canopy flow can be defined as a conservative measure of the gross flow response to the presence of various types of roughness elements. Windspeed profile data of two different canopy density experiments - field and wind tunnel-were analyzed based on least-square fittings. The two sets of index values of canopy flow behave in a similar manner with maxima occurring for optimum densities of $1 / 3$ the potential full array of roughness elements. These index values also differ by some 0.2 , but are still compatible when the 
respective levels of turbulence within these dissimilar canopies is accounted for.

Clary, M.L. (1999) Checklist of mammals from twelve habitat types at Fort Bliss Military Base, 1977-1998. Occasional Papers of the Museum of Texas Tech University; 1-16.

Clary, M.L. (2002) Small mammal communities and habitat associations in the Chihuahuan Desert near Fort Bliss, New Mexico. Occasional Papers of the Museum of Texas Tech University; 215: 1-15.

Cockman, J.S. (1996) Identification of classification parameters for ephemeral drainages in the sacramento mountains of southern New Mexico: Vegetation diversity. PhD. Thesis, New Mexico State University.

Riparian corridors are small in area compared to the surrounding watershed, but their importance is great. In the southwestern U.S., there are three types of riparian corridors: perennial streams, arroyos, and ephemeral drainages. Perennial streams flow water year around and have been studied for their contribution as a water source to man and beast. Arroyos have been studied for their effect in the loss of natural resources due to accelerated erosion. However, little research has been conducted on ephemeral drainages. The purpose of this study was to describe vegetation along ephemeral drainages compared to the adjacent watershed, and to compare types of drainages. The study was conducted in the Sacramento Mountains in southern New Mexico. A univariate model allowed for comparisons of vegetation between types of drainages (submesa-vs.-foothill), elevation (headwater, midwater, tailwater), position (main channel, alluvium, flank, upland) and exposure (northwest, southeast). Response variables included percent foliar cover, plant density, species richness, and height of shrubs and trees. Univariate analyses of variance including contrast statements was conducted to test the primary response variables. Cluster analyses, similarity indices, importance values, and analyses of obligate and exclusive species were conducted to examine species composition and related hypotheses. The univariate analyses showed that the foothill drainage type produced significantly more cover and greater species richness than the submesa. These were greatest in the main channel for all groups of plants except half-shrubs and cacti which were most abundant on the submesa upland positions. Elevation was shown to have an effect throughout the analyses. However, type of drainage and position of sample location were more important in the model. At a minimum, an examination of the drainage to distinguish it from the surrounding watershed should include measures of shrub cover and height. Differences between drainage types is more dependent on species composition than on measures 
of production. Therefore, species presence and the use of tools such as similarity indices were found to be more important than analyses of variance in classifying types of drainages.

Coldren, C.L., T. Mclendon, and W.M. Childress. (2001) Application of the EDYS model to a training area landscape at Fort Bliss, Texas. Technical Report SMI-ES-024, Shepherd Miller Inc. 82 p.

Couvillion, C.E., E.W. Jenney, J.E. Pearson, and M.E. Cocker (1980) Survey for antibodies to viruses of bovine virus diarrhea, bluetongue and epizootic hemorrhagic disease in hunter-killer mule deer (Odicoileus hemionus) in New Mexico, USA. Journal of the American Veterinary Medical Association, 177(9): 790-791.

Sera from male mule deer (O. hemionus) collected in Nov. 1977 in Otero County, New Mexico, were tested for antibodies to bovine virus diarrhea virus (BVDV), bluetongue virus (BTV) and epizootic hemorrhagic disease virus (EHDV). Neutralizing antibodies were detected in 26 of 76 (34\%) sera tested for BVDV (titer gtoreq 1:16). Of 46 sera tested for antibodies to BTV and EHIDV, 10 (22\%) and 3 (7\%), respectively, were positive. Three (7\%) of 46 sera were suspect titer it 1:20) for BTV and 18 (38\%) sera were suspect (titer it 1:20) for EHDV.

Del Divine, D. (1992) Vegetational and ungulate utilization analysis of artificial wildlife watering units on White Sands Missile Range, New Mexico. M.S. Thesis, New Mexico State University.

One season of data failed to reveal any differences in plant abundance or structure in areas surrounding water developments. Poisonous plant species were not more abundant at watering units

Demarais, S., D.J. Tazik, P.J. Geuertin, and E.E. Jorgensen (1999) Ecosystems of disturbed ground. Ecosystems of the World, 16. L.R. Walker. Amsterdam; New York: Elsevier: 385-395.

Fowler, J.M., L.A. Torell, and G. Gallacher (1994) Competitive pricing for the McGregor range; Implications for federal grazing fees. Journal of Range Management, 47(2): 155-158.

Competitive bidding is an acceptable way to determine an efficient price to both buyer and seller. The quasi-competitive bid structure used to price federal forage and lessor-provided services on the McGregor Range in New Mexico indicates that the efficient market price for federal forage, services, and facilities had an upper value of \$4.88/AUM during the 1992 grazing season. The facilities and services provided on the McGregor Range had a 
value of \$1.96/AUM to the ranchers leasing the bombing range. The residual amount of \$2.92/AUM repesents the estimated value of high quality federal forage during 1992. The total cost of grazing McGregor Range was estimated to average \$16.78/AUM during the 1992 production year. This is less than the cost of leasing comparable private land (\$19.68/AUM) or BLM land (\$21.06/AUM) in New Mexico. [References: 13]

Frenzel, P.F., and C.G. Abeyta (1999) Geohydrology of the unsaturated zone and simulated time of arrival of landfill leachate at the water table, municipal solid waste landfill facility, U.S. Army Air Defense Artillery Center and Fort Bliss, El Paso County, Texas. - Water Resources Investigations Report 97-4036, U.S. Geological Survey. 26 p.

Fuchs, E.H. (1997) Sediment removal by water following mechanical surface disturbance on Chuahuan desert soils in New Mexico. M.S. Thesis, New Mexico State University.

This study was conducted to determine the impacts of military tracked M1A1 heavy combat tank and wheeled M998A2 "Humvee" vehicles on sediment loss by water, surface plant basal cover, and surface microtopography in a desert environment. A randomized complete block design was used which had fourteen blocks with four plots $\left(0.5 \mathrm{~m}^{2}\right)$ in each block at one site on a Lozier very gravely loam soil series, and six blocks with four plots $\left(0.5 \mathrm{~m}^{2}\right)$ in each block at another site on a Philder very fine sandy loam soil series. At the Lozier soil series site, each block had randomly selected treatments that included an untreated control, one pass by a Humvee, ten passes by a Humvee, one pass by an M1A1 tank under wet soil conditions, three passes by an M1A1 tank under wet soil conditions, one pass by an MlAl tank under dry soil conditions, and three passes by an M1A1 tank under dry soil conditions. At the Philder soil series site, each block had randomly selected treatments that included an untreated control, one pass by a Humvee, and ten passes by a Humvee. Both sites were located on the New Mexico portion of the Fort Bliss McGregor Guided Missile Range, the Lozier site at military grid coordinates 120616, and the Philder site at military grid coordinates 270880. The sites were chosen for differing soil types. Elevation is 1219 meters and annual precipitation is 0.200 millimeters. It was found that triple pass M1A1 tank impacts had detrimental effects on the Lozier soil site that could last many years, particularly when disturbances were imposed under dry soil conditions, but that Humvee disturbances did not pose a substantial influence beyond one year at one or ten passes at either site. Most sample periods showed that sediment losses from M1A1 tank treatments, single or triple passes under wet or dry conditions, did not differ statistically from 
natural sediment losses under normal rainfall events. However, comparatively heavy rainfall events often generated statistically greater sediment losses from the M1A1 tank triple pass treatments at the Lozier soil study site. Stepwise regression showed that grass cover, litter cover, and microtopographic variance were highly and negatively correlated with cumulative sediment loss at the Lozier soil study site. Other results indicated that the Philder soil study site was more sensitive to disturbance. Depending on precipitation availability, vegetation recovery and soil stability pattern suggest a minimum of three years for most triple pass tank impacts at the Lozier soil study site.

Gallacher, W.G. (1991) Grazing fee evaluation on McGregor Range: A competitive market situation. MS Thesis, New Mexico State University.

Geo Marine Inc. (1994) Ft. Bliss integrated natural resources management plan: Scoping report. Ft. Worth District, U.S. Army Corps of Engineers; Geo-Marine, Baton Rouge, LA.

Gibbs, V., D. Pitts, A.S. Rorex, and R. Giese (1997) A cultural and natural resources survey of approximately 7.3 miles of pipeline right-of-way on Fort Bliss Military Reservation and State Trust Lands, El Paso County, Texas. GeoMarine, Inc.

Gillespie, B.M. (1987) The impact of military maneuvers on eolian transport and soil compressive strength in south central New Mexico. M.A. Thesis, University of Wyoming.

Gilliland, M.W., and P.G. Risser (1977) The use of systems diagrams for environmental impact assessment procedures and an application. Ecological Modelling, 3(3): 183-210.

The utility of systems diagrams and of energy as a unit of measure for environmental impact assessment is illustrated using results from the White Sands Missile Range, New Mexico [USA] Environmental Impact Statement. A set of procedures for developing and evaluating the diagrams is given and applied to White Sands. The utility of results obtained using this method is compared to those obtained from other methods, and the inadequacies of each are discussed. Impacts at White Sands were evaluated at two system levels of detail. At a macroscale, five types of impacts resulting from missile range activities were analyzed. Stresses on the environment caused by those activities represent $1.0 \%$ of the natural energy flow through the system. The effect of water consumption by the Missile Range on the aquifer from which the water is obtained was analyzed by means of a hydrologic model. Model simulations indicated that salt water intrusion into the aquifer was eminent 
and identified two aquifer management strategies that could prevent that intrusion.

Goran, W.D., L.L. Radke, and W.D. Severinghaus (1983) An overview of the ecological effects of tracked vehicles on major U.S. Army installations. CERL TR N-142, U.S. Army Construction Engineering Research Laboratory, Champaign, IL.

Various levels of field studies were done on 12 U.S. Army Training Doctrine Command (TRADOC) and U.S. Army Forces Command (FORSCOM) installations to provide a general overview of ecological disturbance cause by tactical vehicle training. Detailed quantitative and qualitative data were obtained from Forts Polk, Knox, Hood, and Lewis; supplementary semiquantitative and qualitative studies were done at Forts Benning, Bliss, Carson, Drum, Irwin, Riley, and Stewart, and at Yakima Firing Range.

Hamazaki, T., K.G. Boykin, and B.C. Thompson (2001) Incorporating landscape context in conservation planning models for Fort Bliss Military Reservation, New Mexico and Texas. New Mexico Cooperative Fish and Wildlife Research Unit. 66 p.

Hamazaki, T., B.C. Thompson, B.A. Locke, and K.G. Boykin (2003) Analysis of ecological context for identifying vegetation and animal conservation planning foci: An example from the arid southwestern United States. Journal of Environmental Planning and Management, 46(2): 239-256.

Hansen, R.M. (1976) Foods of free-roaming horses in southern New Mexico. Journal of Range Management, 29(4): 347.

White Sands Missle Range had 150-200 wild horses in 1974. At this level of population they did not appear to be causing range deterioration.

Hernando, A.M. (1999) Effects of military wheeled vehicles on soil compaction in the Chihuahuan Desert. M.S. Thesis, University of Texas.

Heywood, C.E., and R.M. Yager (2003) Simulated ground-water flow in the Hueco Bolson, an alluvial-basin aquifer system near El Paso, Texas. Water Resources Investigations Report 02-4108, U.S. Dept. of the Interior, U.S. Geological Survey. 73 p.

Hinojos, J., and A. Canaris (1988) Metazoan parasites of Himantopus mexicanus muller (Aves) from southwestern Texas, with a checklist of helminth parasites from North America. Journal of Parasitology, 74(2): 326-331.

Nineteen species of helminths were recovered from 34 of 35 black-necked stilts, Himantopus mexicanus Muller, collected from the Fort Bliss ponds, El 
Paso County, Texas. New host records are marked with an*. The species identified were: Acoleus vaginatus, Davainea himantopodis, Diplophallus polymorphus, *Eurycestus avoceti, Hymenolepis himantopodis, Hymenolepis sp. 1, Infula macrophallus, Cloacitrema michiganensis, Cyclocoelum lanceolatum, Notocotylus sp., Parastrigea mexicanus, *Tanaisia fedtschenkoi, Capillaria sp., ${ }^{*}$ C. anatis, ${ }^{*}$ C. controta, ${ }^{*}$ C. mergi, *Chevreuxia americana, Eustronglydes mergorum, and *Splendidofilaria sp. Six species of mallophagan lice and 1 species of nasal mite, Rhinonyssus himantopus, were recovered. Helminths showed little concentration for dominance (0.09), were not very evenly distributed ( 0.49 plus or minus 0.08$)$ nor very diverse ( 0.73 plus or minus 0.14 ), and most species were highly aggregated. The helminth community consisted of an unusually large number of core species (10). Three large species of tapeworms exhibited mostly paired infections, were mutually exclusive, and were negatively associated $(-1)$.

Hochstrasser, T., D. Peters, J. Fehmi, and K. Vonfinger (2002) A bibliography of important plant species in the Chihuahuan Desert of North America (1904-2002). ERDC/CERL Special Report 02-08, U.S. Army Engineer Research and Development Center, Construction Engineering Research Laboratory, Champaign, IL.

The Chihuahuan Desert covers an area of $453,000 \mathrm{~km}^{2}$ in the United States and Mexico. Managers of military lands in the desert require a detailed understanding of installation natural resources. A comprehensive bibliography of current research and information on desert plants can is needed. The objective of this work was to assemble as much published ecological information as possible about five dominant arid land species found in the North American Chihuahuan Desert. The species of focus were selected because of their importance in the desert grassland and shrubland communities of the desert. Chapter 2 contains selected references that significantly contribute to the understanding of arid land ecology, but do not specifically speak about the species of interest. Chapter 3 contains reference information on Bouteloua eriopoda (black grama). Chapter 4 contains references on Pleuraphis mutica (=Hilaria mutica, tobosa). Chapter 5 contains Larrea tridentata (creosotebush). Chapter 6 contains Prosopis glandulosa (honey mesquite). Chapter 7 contains Flourensia cernua (tarbush). Furthermore, information gathered on an important subdominant half-shrub, Gutierrezia sarothrae (=Xanthocephalum sarothrae, broom snakeweed), is presented in Chapter 8 . Chapter 9 contains reference information on the ecology of annual species. 
Johnson, D. (1997) Geomorphological, geoecological, geoarcheological, and surficial mapping study of McGregor Guided Missile Range, Fort Bliss, New Mexico. Volume I. Geo-Marine, Inc. 412 p.

The scope of the study is reflected in its title: to provide a general geomorphologic, soil, geoarcheologic, and surficial mapping study of the McGregor Range. The purpose is to produce an explanatory model of Quaternary landscape evolution. The study is also intended to provide baseline information on the geology, water resources, landforms, and soils of the McGregor Range, plus explore new and old concepts and background information as a collective intellectual resource base for future environmental assessments, for resource management, and for mitigation and compliance considerations. In one sense this is geoarcheological study, but in another it is a geocological study, one that focuses en the dynamic processes that have operated to produce the modern landscape of McGregor Range and environs. This study included a three-day reconnaissance of parts of the McGregor Range.

Jones, T.L., M. Montes-Helu, and Q.B. Xie (1996) Ecological studies on McGregor Range hydrologic studies task: Final report. Department of Agriculture and Home Economics, New Mexico State University.

Jorgensen, E.E., and S. Demarais (1998) Herpetofauna associated with arroyos and uplands in foothills of the Chihuahuan Desert. Southwestern Naturalist, 43(4): 441-448.

Jorgensen, E.E., S. Demarais, and S. Neff (1995) Rodent use of microhabitat patches in desert arroyos. American Midland Naturalist, 134(1): 193-199.

Rodents were rarely captured in wash zones. They were captured on shoulders half as much as terrace. We confirmed past observations that crictines tend to move farther than heteromyids.

Jorgensen, E.E., S. Demarais, S.M. Sell, and S.P. Lerich (1998) Modeling habitat suitability for small mammals in Chihuahuan Desert foothills of New Mexico. Journal of Wildlife Management, 62(3): 989-996.

Habitat associations of 18 species of small mammals in 6 habitats associated with desert foothills in the Sacramento Mountains remained relatively consistent through time, although community abundance decreased 34\% from spring 1993 to fall 1994. The proceedure successfully classified 8093\% of habitats as supporting "high," "moderate," or "low" abundance of 13 species of heteromyid and murid rodents. Murid rodents (Peromyscus, Reithrodontomys, Neotoma, and Sigmodon) were found primarily within 
arroyos where shrub diversity, canopy cover, and height were greatest compared to surrounding habitats.

Jorgensen, E.E., S. Demarais, and W.R. Whitworth (1994) The effect of boxtrap design on rodent captures. Southwestern Naturalist, 39(3): 291-294.

Side by side comparisons of wire-mesh and Sherman traps were made at Ft. Bliss and in Lubbock. Sherman traps were more effective, which may be due to the more sensitive treadle.

Kozma, J., and N.E. Mathews (1995) Cooperative nesting between barn swallows and Say's phoebes in south-central New Mexico. The Auk, 112(2): 515-517.

Describes an unusual type of nesting arrangement between two avian species observed at Fort Bliss, TX/NM.

Kroll, A. (2000) Comparative ecology and conservation of the genus Ashmunella (Gastropoda: Pulmonata: Polygyridae) of White Sands Missile Range (NM) and Fort Bliss (NM and TX). The American Malacological Society 2000 Annual Meeting, San Francisco, CA, 7-12 July 2000.

Kroll, A.J. (2001) Habitat characteristics and conservation of the genus Ashmunella (Gastropoda: Pulmonata: Polygyridae) of White Sands Missile Range (NM and TX) and Fort Bliss (TX). M.S. Thesis, New Mexico State University.

Kroll, A.J. (2003) Comments on the natural history of the Ashmunella (Gastropoda: Pulmonata: Polygyridae) of White Sands Missile Range (New Mexico, USA) and Fort Bliss (New Mexico and Texas, USA). Veliger, 46(1): 98-99.

Kroll, A.J., K.G. Boykin, B.C. Thompson, and D. Daniel. (2003) Habitat characteristics and conservation of the genus Ashmunella (Gastropoda: Pulmonata: Polygyridae) of White Sands Missile Range (NM and TX) and Fort Bliss (TX). Southwestern Naturalist, 48(1): 14-22.

We studied the habitat characteristics of seven species of montane land snails in the genus Ashmunella in southern New Mexico from July 1999 to September 2000. We compared nine numeric variables and four categorical variables by species. Geographic differences in microhabitat variables exist among these species; however, these differences tend to be obscured when comparing species, because some species are ecological generalists that occupy a wide range of habitat types. Although this study determined that different populations occupy ecologically distinct habitats in a broad range of environmental conditions, it remains unclear whether these factors influence 
the morphological characters on which past workers assigned species status. Management plans for the conservation of these species should take careful note of demonstrated habitat differences among and within the species.

Mackay, W.P., and J. Herrick (1996) The impact of wheeled vehicle maneuvering on the flora and fauna of the Chihuahuan Desert. Second report submitted to the U.S. Army Corps of Engineers, University of Texas.

Mackay, W.P., J. Oliver, V. Mendoza, L. Lenart, R. Guerrero, H. Navarro, M. Gaglio, and J. Herrick (1996) The impact of wheeled vehicle maneuvering on the flora and fauna of the Chihuahuan Desert. Fourth report submitted to the U.S. Army Corps of Engineers, University of Texas.

Mackay, W.P., S. Watts, V. Mendoza, and J. Oliver (1997) The impact of wheeled vehicle maneuvering on the flora and fauna of the Chihuahuan Desert. Seventh report submitted to the U.S. Army Corps of Engineers, University of Texas.

Martin-Bashore, T.E., C.L. King, and D.E. Bell (1996) An annotated bibliography and natural history database of the amphibians and reptiles of Fort Bliss, Texas. Department of the Army, Headquarters, U.S. Army Defense Artillery Center and Fort Bliss. 547 p.

Results of a literature survey for reptiles and amphibians potentially occurring on or within $80 \mathrm{~km}$ of Fort Bliss, El Paso, Texas was conducted from 5 February, 1996 to 3 May, 1996. It is expected that the information gathered by this literature review will be utilized when making management decisions for these species.

Mclendon, T., M.W. Childress, and C. Coldren (1999) EDYS 2: First year validation results for a black grama desert grassland community, Fort Bliss, TX. Shepherd Miller, Inc.

Mclendon, T., W.M. Childress, and C. Coldren (2000) EDYS applications: Two-year validation results for grassland communities at Fort Bliss, Texas, and Fort Hood, Texas. SFIM-AEC-EQ-CR-20004-7, U.S. Army Environmental Center.

The Ecological Dynamics Simulation (EDYS) model is a personal computer based, mechanistic model that is a useful evaluation and planning tool for instigating potential plat, animal, and hydrological responses to anthropogenic and natural stressors in a wide variety of ecological systems. It can be used to simulate effects of military training, drought, fire, grazing, and soil nitrogen availability on grassland communities. 
Experimental field validation plots were established on Fort Bliss, Texas, and Fort Hood, Texas to test the accuracy of EDYS in predicting species and community dynamics in response to water and nitrogen availability. Baseline data were collected in early 1998; the plots were resampled at the end of the growing seasons in 1998 and 1999. EDYS simulations were run using parameterization based on these baseline data. The predicted 1998 and 1999 values from the simulations were compared to the sampled values to calculate accuracies of first- and second-year simulations.

The results of this two-year validation study indicate that EDYS is an effective and accurate tool for predicting vegetation responded to both natural ecological stressors and changes in management scenario in a desert grassland and a midgrass prairie. EDYS second-year accuracies were 9499\% for total aboveground biomass, 89-99\% for total grasses, 82-96\% for major species, and $70-83 \%$ for all species on a weighted biomass basis. EDYS effectively simulated plant community responses to fire, livestock grazing, successional status, precipitation variation, and change in soil nitrogen availability.

Mclendon, T., W.M. Childress, C. Coldren, and D. L. Price (2001) EDYS experimental and validation results for grassland communities. Final rept. ERDC/CERL-TR-01-54, U.S. Army Engineer Research and Development Center, Construction Engineering Research Laboratory, Champaign, IL. 90 p.

Precipitation patterns, including the effects of long-term droughts or above average precipitation and the interactions with nitrogen availability, often have enough influence on plant growth that the effects of our use or management of land are not apparent. This is especially true because of the need to judge changes in land condition over periods of months to years. One of the primary information requirements identified by Army land managers and trainers is the need to be able to project the impacts of training and management strategies on the amount of plant cover protecting the soil. Managers also need to know how long it takes a plant community to recover to the desired plant cover level after use. The purpose of this research project was to test the ability of the Ecological Dynamics Simulation (EDYS) model to accurately project plant dynamics given a wide range of precipitation patterns and nitrogen availability over a period of years to decades. The results of this research show that EDYS did accurately simulate changes in plant cover over the 2-year research period and the patterns EDYS projects over 40-year simulations closely match the patterns seen on the ground in 40year old research plots. 
Mclendon, T., W.M. Childress, D.L. Price, and A.B. Anderson (1998) A successional dynamics simulation model as a factor for determining military training land carrying capacity. CERL TR 98/90, U.S. Army Construction Engineering Research Laboratory, Champaign, IL. 24 p.

The U.S. Army is committed to good stewardship of lands within military installations. The Army is also committed to achieving "training to standard" for its forces and therefore is interested in a method of determining optimum levels of training activities such that military preparedness is maximized and ecological impacts and their costs are minimized. A key requirement to the successful implementation of such an optimization is the development of a successional dynamics model that predicts ecological responses to military and non-military stressors. A prototype simulation model has been developed, in part, using Land Condition Trend Analysis (LCTA) data from five Army installations. The model is based on responses of individual species and ecological processes to stressors. The model currently has climatic, edaphic, plant, decomposition, and animal modules. Current stressors include drought, nitrogen, fire, herbivory, and tactical maneuvers. The core model is adapted to forest, grassland, shrubland, and desert ecosystems. Site-specific data can be added to calibrate the model to a specific ecosystem within an installation. The model has been calibrated with LCTA data and applied to multiple plant communities at five installations: Fort Bliss, TX; Fort Carson, CO; Fort Hood, TX; Fort Riley, KS; and Yakima Training Center, WA.

Mendoza, V.B., S.H. Watts, R.A. Guerrero, A.M. Hernando, M.P. Perez, M.D. Gaglio, and W.P. Mackay (1997) The impact of wheeled vehicle maneuvering on the flora and fauna of the chihuahuan desert. Final report submitted to the U.S. Army Corps of Engineers, University of Texas.

Minor, T.B., J. Lancaster, T.G. Wade, J.D. Wickham, W. Whitford, and K.B. Jones (1999) Evaluating change in rangeland condition using multitemporal AVHRR data and geographic information system analysis. Environmental Monitoring and Assessment, 59(2): 211-223.

Coarse-scale, multitemporal satellite image data were evaluated as a tool for detecting variation in vegetation productivity, as a potential indicator of change in rangeland condition in the western U.S. The conterminous U.S. Advanced Very High Resolution Radiometer (AVHRR) biweekly composite data set was employed using the six-year time series 1989-1994. Normalized Difference Vegetation Index (NDVI) image bands for the state of New Mexico were imported into a Geographic Information System (GIS) for analysis with other spatial data sets. Averaged NDVI was calculated for each 
year, and a series of regression analyses were performed using one year as the baseline. Residuals from the regression line indicated 14 significant areas of NDVI change: two with lower NDVI, and 11 with higher NDVI. Rangeland management changes, cross-country military training activities, and increases in irrigated cropland were among the identified causes of change.

Montes-Helu, M.C. (1997) Track-vehicle disturbance on rangeland and design of SAP flow guage for desert shrubs. PhD. Thesis, New Mexico State University.

Rangelands of the arid southwest are used extensively for military training. The impact of track-vehicle traffic on the Ft. Bliss military reservation were evaluated in soil water balance. Military training can reduce vegetation and accelerate erosion. Sustainable management will result from balancing disturbance intensity with recovery times. Military activities can occur during all seasons and the possible impact in the ecology can vary. Season and soil types produce different impact. The objectives of this study were to measure the soil disturbance caused by track-vehicles and the resulting change in site water balance. Soil disturbance was analyzed with the change in the bulk density, microrelief and erosion rods. Bulk density changed (increased) depending the number of tank passes and season. The surface micro-topography was modified by the tank and remained months after the tank passed. Erosion rods showed soil removal and deposition. Water storage increased about one to $2 \mathrm{~cm}$ for 5 pass treatments in one site. There was a slight increase of water storage right after the tank because the destruction of the vegetation reduced plant transpiration. The Penman method estimated a lower potential evapotranspiration (PET) values than expected under irrigation conditions. Dry soil surface and low vegetative covers produced low net radiation. A relationship between total rain and runoff measures was used in the water balance to estimate runoff. The overall water balances, assuming zero drainage shows that all the rain was used in ET. The actual evapotranspiration (AET) was about 15\% of PET. During the growing season the AET is $0.25 \mathrm{~cm} \mathrm{day}^{-1}$ in the wettest sites. Dry Sites had a maximum AET of 0.15 to $0.20 \mathrm{~cm} \mathrm{day}^{-1}$. Direct measurement of plant transpiration has always been a problem under natural conditions. One way to estimate of plant transpiration is the heat balance method. This is an application of heat and accounting the heat input and output used to measure the water flow assuming study-state conditions. The main objective was to design a sap flow gauge that can regulate the quantity of heat required depending on sap flow conditions and avoid the stem damage by overheating when there is low flow. Controlling heat input to maintain constant temperature difference keeping steady-state condition does not appear to damage the stem. The 
simple design does not allow adequate correction for conduction losses. The three thermocouple design allows correction for conduction losses. However, calibrations before installation in the field are not possible. Portable heat balance design allows laboratory calibrations before field installation. There was a good agreement between the measurements and the calculated water flux under laboratory conditions. Under greenhouse conditions, the heat balance method calculated the water flow in potted pecan plants quite well when compared with measured water loss.

Perez, M.P. (1999) Impact of military wheeled vehicles on water infiltration rates of Chihuahuan Desert soils. M.S. Thesis, University of Texas.

Perez, M.P., A.M. Hernando, and W.P. Mackay (1999) Impact of wheeled vehicle maneuvering on soils of the Chihuahuan Desert: Annual review of ARO Terrestrial Sciences Program. University of Texas.

Pidgeon, A.M. (2000) Avian abundance and productivity at the landscape scale in the northern Chihuahuan Desert. PhD. Thesis, University of Wisconsin.

Many theories about habitat selection have been invoked to explain the spatial and temporal patterns within animal populations. This dissertation addresses questions about spatial and temporal patterns of habitat use by avian communities in the northern Chihuahuan Desert, and suggests causal mechanisms for these patterns. The study area was McGregor Range, Ft. Bliss Military Reserve, in south central New Mexico. It encompasses 2825 $\mathrm{km}^{2}$, and spans an elevation range of $1200-2400 \mathrm{~m}$. Field data in seven habitats was collected March-August, 1996-1998. The research question of chapter 1 was whether the breeding bird community has changed due to habitat conversion from grassland to shrubland from the time of European settlement to the present. Second, I asked whether breeding bird communities in the four dominant shrubland habitat types display distinct habitat associations. I estimated changes in the avian community since the 1880s and assessed landcover change of 5 habitat types through analysis of U.S. Government Land Office records. Present day vegetation patterns and avian abundance patterns were compared with 1880s data. First, I concluded that there has been a major turnover in avian community composition in the study area since the 1880s. Moreover, avian community distribution and abundance is distinct among the four shrub communities. The research question of Chapter 2 is how do patterns of productivity of avian species vary through space and time. To address this problem, I developed a method for scaling up plot-based nest success estimates to the landscape level in a way that controls for accuracy and assigns a measure of confidence to estimates. I examined differences in nesting success rates for 18 species, among 7 habitats and 
among years. I found that there is great variability in resource use among years, and that the assumption that nest success is correlated with nest abundance is not valid. The ecological patterns and processes researched in this desert ecosystem contribute to understanding of habitat selection for animal populations as a whole. The landscape scale and temporal scope provide context for understanding local, present day patterns as well as broad, region-wide conservation assessments.

Pidgeon, A.M., V.C. Radeloff, and N.E. Mathews (2003) Landscape-scale patterns of black-throated sparrow (Amphispiza bilineata) abundance and nest success. Ecological Applications, 13(2): 530-542.

Analyses of avian demographic patterns across entire, contiguous landscapes are rare, but such analyses are important for understanding population dynamics. We selected the black-throated sparrow in the northern Chihuahuan Desert as a model to test patterns of abundance and nest success across a landscape. We integrated abundance, nest density, and nesting success measured on sampling plots with a classified satellite map of the distribution of seven habitat types to analyze spatial and temporal patterns contributing to the population dynamics of this species. Adult relative abundance ranged from $<1$ bird/100 ha in pinyon-juniper habitat to 24-39 birds/100 ha in shrubland habitats. Nest density was consistently high in mesquite, moderate to high in creosotebush, and low in black grama grassland; this value exhibited more temporal variability than relative abundance of adults. Nest success rates exhibited a strong habitat effect and ranged from $8 \%$ in mesquite to $47 \%$ in black grama grassland; overall population nest success was 0.266 . In all three years, nest success in mesquite was significantly lower than in all other habitat types $(\mathrm{P}<0.01)$ There was no correlation between nest success and adult relative abundance. While mesquite habitat contained about one-third of all adults in the three years of the study, it contributed as little as $10 \%$ of successful nests. In creosotebush, the relative contribution to both adult abundance and successful nests was relatively high. Mesa grassland contained relatively few adults, but up to $44 \%$ of successful nests. We discuss how habitat selection theory suggests mechanisms for the observed patterns. Mesquite appears to be a population sink for Black-throated Sparrows and may be an ecological trap. While we do not propose that there is cause for conservation concern for this widespread species, our results underscore the pitfalls associated with using adult abundance as an indicator of habitat quality. The method presented here is applicable for many species and ecosystems and, thus, may be an important tool for conservation and management, as well as a new avenue for scientific investigation of landscape-level population dynamics. 
Rivieccio, M. (2000) Validation of predictive habitat modeling for the Colorado chipmunk (Tamias quadrivittatus) in southern New Mexico. MS Thesis, New Mexico State University.

Rivieccio, M., B.C. Thompson, W.R. Gould, and K.G. Boykin (2004) Habitat features and predictive habitat modeling for the Colorado chipmunk in southern New Mexico. Western North American Naturalist.

Rodrick, P.J. (1999) Morphological, genetic and den site characteristics of the kit fox (Vulpes macrotis) on McGregor Range in south central New Mexico. MS Thesis, University of Wisconsin.

Rodrick, P.J., and N.E. Mathews (1999) Characteristics of natal and non-natal kit fox dens in the northern Chihuahuan Desert. Great Basin Naturalist, 59(3): 253-258.

We studied kit fox den characteristics on the northern McGregor Range of Fort Bliss Military Reservation, New Mexico, during 1994 and 1995. Twenty radio-collared kit foxes used 132 different dens, including 16 natal dens. Kit fox dens were located primarily in creosote-dominated habitat found in relatively flat, well-drained terrain. Natal dens were virtually indistinguishable from non-natal dens; however, natal den entrances were taller than non-natal den entrances. Entrances found at all dens were oriented more frequently toward the northwest and southeast. Kit foxes used more new dens during the breeding (January-February) and pup-rearing season (May-July) than during gestation.

Science Applications International Corporation (1998) Fort Bliss mission and master plan programmatic environmental impact statement. U.S. Army Air Defense Artillery Center and Fort Bliss; U.S. Army Corps of Engineers, Fort Worth District; and Science Applications International Corporation.

Addresses the potential environmental impacts of the approval of revisions to components of the Fort Bliss Real Property Master Plan and adoption of the Integrated Natural Resources Master Plan, Integrated Cultural Resources Management Plan, and the Training Area Development Concept, as well as modifying the general land use plan to increase the availability of controlled access Field Training Sites in the Fort Bliss Training Complex

Science Applications International Corporation (1998) McGregor Range land withdrawal draft legislative environmental impact statement. U.S. Army Air Defense Artillery Center and Fort Bliss; U.S. Army Corps of Engineers, Fort Worth District. 
Science Applications International Corporation (1998) McGregor Range, New Mexico land withdrawal renewal: Economic report. U.S. Army Corps of Engineers, Fort Worth District.

Science Applications International Corporation (1998) McGregor Range, New Mexico land withdrawal renewal: Land use study. U.S. Army Corps of Engineers, Fort Worth District.

Science Applications International Corporation (1999) McGregor Range land withdrawal legislative environmental impact statement. U.S. Army Air Defense Artillery Center and Fort Bliss; U.S. Army Corps of Engineers, Fort Worth District.

Science Applications International Corporation (2000) Fort Bliss mission and master plan final programmatic environmental impact statement. U.S. Army Air Defense Artillery Center and Fort Bliss; U.S. Army Corps of Engineers, Fort Worth District.

This PEIS includes analyses of the environmental consequences that each of four alternatives may have on land use, infrastructure, airspace, earth resources, air quality, water resources, biological resources, cultural resources, noise, safety, hazardous materials, socioeconomics, and environmental justice.

Silcox, S. (1995) Impacts of wheeled vehicles on surface water, infiltration, and erosion: Fort Bliss. M.S. Thesis, New Mexico State University.

Smith, C., R. Valdez, J.L. Holechek, P.J. Zwank, and M. Cardenas (1998) Diets of native and non-native ungulates in southcentral New Mexico. Southwestern-Naturalist, 43(2): 163-169.

Botanical diet composition of pronghom (Antilocapra americana), gemsbok (Oryx gazella), and feral horses (Equus caballus) on White Sands Missile Range, New Mexico, was determined using fecal analysis. Pronghorn diets consisted of $58 \%$ shrubs, $20 \%$ grasses, $17 \%$ forbs, and 500 unknowns. Gemsbok diets consisted of $83 \%$ grasses, $16 \%$ shrubs, and $<1 \%$ forbs and unknowns. Horse diets consisted of $91 \%$ grasses, $8 \%$ shrubs, and $<1 \%$ forbs and unknowns. Dietary overlap was greatest between horses and gemsbok, and least between horses and pronghorn. Pronghorn diets overlapped least with those of horses and gemsbok, probably due to greater diversity of pronghorn diets. Key forage species (gtoreq 5\% seasonal diet) selection varied each season among animal species suggesting the importance of season in relation to diet selection and forage diversity. 
Stafford, A.T.I. (1986) Fort Bliss soil degradation study. MS. Thesis, University of Texas at El Paso.

The degradation of United States Army training ranges by the physical damage caused to soil, flora, and fauna environments from maneuvering military vehicle has a major impact on future training. There are many processes that contribute to degradation of training ranges. Vehicle maneuver damage causes immediate and long term degradation of training areas. This study collected, measured and analyzed plant, soil, and meteorological parameters and compared them to the amount of tracked and wheeled vehicles passing through transects located in four grassland ecosystems on McGregor range and Fort Bliss, Texas from June 1985 until March 1986. The study found a correlation between the number of vehicle passes through a transect and a decline in the number of plants in it. Soil textural changes occurred in the surface A horizons on those transect incurring vehicle damage. Available nitrate nitrogen values were lower on vehicle damaged sites than on the undamaged control site. A greater seasonal fluctuation occurred with grasses and forbs on the vehicle damaged sites, than on the undamaged control site.

Tweddale, S., W. Jackson, and P. Pope (2002) Estimating vegetation cover case study spectral demixing and spectral index correlations for sub-pixel quantification of land cover components from coarse resolution imagery at Fort Bliss, Texas. Remote Sensing Users' Guide, Version 2.5. (T.A. Bright and S. Getlein, ed.). U.S. Army Environmental Center. 234 p.

Tweddale, S.A. (2001) Historical analysis of land cover/condition trends at Fort Bliss, Texas, using remotely sensed imagery. ERDC/CERL TR-01-36, U.S. Army Engineer Research and Development Center, Construction Engineering Research Laboratory, Champaign, IL. 68 p.

Fort Bliss, Texas, is a Training and Doctrine Command installation located in the semi-arid northern Chihuahuan Desert of western Texas and south central New Mexico. Military training (both tracked and wheeled vehicles), grazing, and recreational activities act as stressors on the landscape. The natural resource managers need information on land condition to make informed land management decisions and to support conservation and compliance efforts. They need a cost-effective method of assessing and monitoring land condition. The objective of this research was to characterize the small scale, gross level change in land condition on a selected area of Fort Bliss over a 23-year period. The evaluation and analysis was based on several vegetation and brightness indices calculated from temporal, archival multispectral imagery. Trends in brightness and greenness indices varied considerably. 
Most variation could be due to natural differences in the amount of precipitation in the region. There was no indication of permanent, long-term changes in the land condition. The study area appeared to be resilient, with no clearly observable trends in either long-term degradation or improvement. The brightness and greenness indices calculated from temporal image data sets provides a cost-effective method for monitoring relative trends in land condition.

\section{U.S. Army Air Defense Artillery Center, Fort Bliss Conservation Division, Geo-Marine Inc., Science Applications International Corporation, Colorado State University Center for Ecological Management of Military Lands, and U.S. Army Corps of Engineers Fort Worth District (1998) Integrated natural resources management plan: U.S. Army Air Defense Artillery Center, Fort Bliss, Texas and New Mexico. U.S. Army Air Defense Artillery Center and Fort Bliss, Conservation Division; Geo-Marine, Inc.; Science Applications International Corporation; Colorado State University, Center for Ecological Management of Military Lands; U.S. Army Corps of Engineers, Fort Worth District.}

URS Corporation (2001) McGregor Range resource management plan amendment and environmental impact statement. Scoping summary report. U.S. Dept. of the Interior, Bureau of Land Management, Las Cruces District Office; URS Corporation. 23 p.

Vogel, M., and S. Demarais (1996) Effects of fire on herpetofauna of the northern Chihuahuan Desert, Fort Bliss TX/NM. 76th Annual Meeting of the American Society of Ichthyologists and Herpetologists, New Orleans, LA, 13-19 June 1996.

Wilson, C.A., and R.G. Myers (1981) Ground-water resources of the Soledad Canyon re-entrant and adjacent areas, White Sands missile range and Fort Bliss Military Reservation, Dona Ana County, New Mexico. Water Resources Investigation 645, U.S. Geological Survey. 20 p.

Wood, K.M., S. Silcox, and E. Fuchs (1996) Final report: Surface water and erosion component tank maneuver studies. New Mexico State University. 


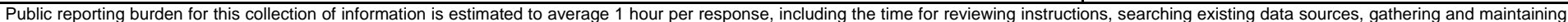

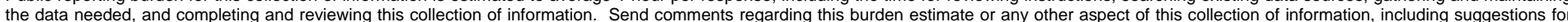

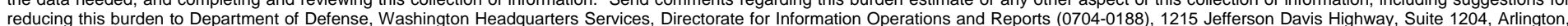

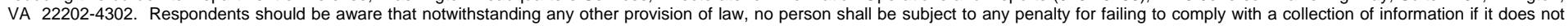
display a currently valid OMB control number. PLEASE DO NOT RETURN YOUR FORM TO THE ABOVE ADDRESS.
1. REPORT DATE (DD-MM-YYYY) 2. REPORT TYPE
November 2005
Technical Report

Available Conservation Research for Fort Bliss

\section{AUTHOR(S)}

Jeffrey S. Fehmi and Bruce A. MacAllister
4. TITLE AND SUBTITLE

\section{DATES COVERED (From - To)}

5a. CONTRACT NUMBER

5b. GRANT NUMBER

5c. PROGRAM ELEMENT NUMBER

5d. PROJECT NUMBER

622720896

5e. TASK NUMBER

5f. WORK UNIT NUMBER

CNN-T081

8. PERFORMING ORGANIZATION REPORT NUMBER

ERDC/CERL TR-05-37

U.S. Army Engineer Research and Development Center

Construction Engineering Research Laboratory

2902 Newmark Drive

Champaign, Illinois 61826-9005

\section{SPONSORING / MONITORING AGENCY NAME(S) AND ADDRESS(ES)}

10. SPONSOR/MONITOR'S ACRONYM(S)

Office of the Directorate of Environmental Programs (DAIM)

Assistant Chief of Staff (Installation Management)

Fort Bliss

\section{DISTRIBUTION / AVAILABILITY STATEMENT}

Approved for public release; distribution is unlimited

\section{SUPPLEMENTARY NOTES}

\section{ABSTRACT}

In the last 10 years there have been numerous conservation-related research projects conducted on and related to Fort Bliss, Texas.

These projects, while supporting Fort Bliss's conservation goals, have been done by numerous federal agencies and other nongovernmental organizations, universities, and consultants. The resulting combination of technical reports, masters theses, doctoral dissertations, research articles, and proceedings papers make it difficult for managers to distill the appropriate pieces of the research into answers to their land management questions. This project was initiated to summarize and consolidate the available research on conservation, natural resources, and land management at Fort Bliss into a more cohesive and usable form. A secondary objective was to provide a number of the reports in electronic form for easier access and to help ensure that the reports remain available beyond the one copy or the few printed copies now in existence.

\section{SUBJECT TERMS}

Bibliography

Conservation
16. SECURITY CLASSIFICATION OF:

\section{a. REPORT}

U

\section{Fort Bliss}

